\title{
An Overview of Effects of Carbonated Drinks
}

\author{
Bint-E-Zahra, Saniha Shoaib, Rana Khalid Iqbal* \\ Institute of Molecular Biology \& Biotechnology Bahauddin Zakariya University, Multan - 60800, Pakistan.
}

\begin{abstract}
Soft drinks are those drinks which do not contain alcohol. These soft drinks are either carbonated or non-carbonated soft drinks. Carbonated soft drinks are consumed widely across the globe. Today, when people are becoming more health conscious, concerns are being raised regarding the impact of carbonated soft drinks on health. When discussing the effects of carbonated soft drinks on health carbon dioxide, phosphoric acid and sugar are of main concern. Most carbonated beverages have acidic $\mathrm{pH}$ which results in gastroesophageal reflux disease (GERD) like symptoms. The phosphoric solution in these beverages is powerful enough to cause human teeth to become soft. The caffeine present in colas is known to be a hazardous factor for osteoporosis. When taken after a period of dehydration, the sugar in these beverages is known to cause more renal injury then plain water. The sugar content in these beverages may lead to lipids production in the body and result in obesity, hypertension, non-alcoholic fatty liver disease (NAFLD), and pancreatic cancer. Hence, it is necessary to monitor diet and focus on natural and healthy beverages.
\end{abstract}

Keywords: Soft drinks, Side-effects, Diseases, Obesity, Tooth erosion, Hypertension.

\section{INTRODUCTION}

A carbonated beverage or an effervescent drink may be a nonalcoholic drink that ordinarily contains water, a sweetener, corrosive and a seasoning ingredient. The term "soft" is owing to the absence of alcohol, not like its presence in exhausting drinks [1]. Carbonation may be a term accustomed establish the dissolution of greenhouse emission gas in water utilizing pressure and temperature [2]. The effervescent drinks are the third most consumed beverages, across the globe [3].

Artificial carbonation was invented by Joseph Priestly, in 1767. First commercial production of carbonated drink was in Switzerland, in 1783. It was mineral water [4].

Carbonated drinks are consumed worldwide [5] and the majority of the people drink them daily, making them the easiest source of energy intake. Given the high consumption of these drinks, the scientific community is concerned about their impact on health [6]. An association between carbonated drinks and obesity or the metabolic syndrome has been hypothesized, however conjointly, dental, pneumonic or cardiovascular diseases are associated with their consumption

[6]. This review provides information concerning the consequences of carbonated drinks on health. This information can be used for lifestyle changes, relating to the frequent consumption of carbonated soft drinks.

\section{HEALTH EFFECTS OF CARBONATED SOFT DRINKS}

\section{Effects on the Gastrointestinal Tract}

Different teams have proposed a negative impact while others

*Address correspondence to this author at the Institute of Molecular Biology \& Biotechnology Bahauddin Zakariya University, Multan - 60800,

Pakistan. E-mail: khalid.iqbal@bzu.edu.pk

doi.org/10.21089/njhs.42.0080

(ㄷ) 2019 NIBD Publications have depicted advantageous impact while expending carbonated refreshments under various conditions [7].

When talking about the impact of carbonated drink on human wellbeing, more explicitly, its impact on gastrointestinal tract carbonation is of main concern. Carbon dioxide occurs normally in the body as the result of breath altogether cells. Be that as it may, as bicarbonate it has different jobs in the human body including influencing blood's pH balance, adds to vasodilation, aggravation and tissue recovery and the stimulus of relaxation [7-11].

When the bottle is opened most of the carbon dioxide escapes, and very little amount reaches the digestive tract. Indeed, even the visual picture of the rises in the drink apparently connected with wonderful responses recently experienced with that equivalent can alter gastrointestinal observation [12-14].

\section{Esophagus}

The connection between carbonated soft drink consumption and esophagus is said to the matter of gastroesophageal reflux disease (GERD). The most common indication of GERD is heartburn [15].

Carbonated beverages have distinctive properties that may worsen gastroesophageal reflux diseases such as a large amount of acidity and carbonation [16].

Numerous carbonated drinks have acidic $\mathrm{pH}$ and result in GERD like symptoms [17, 18].

\section{Effects on Oral Health}

The excess drinking of carbonated soft drinks harms the teenage population because it contains no vital nutrients and harms their general and oral health. The ingredients involve in

www.njhsciences.com 
carbonated soft drinks are phosphoric acid, sugar, caffeine, coloring and seasoning agents. Phosphoric acid is the active ingredient in these drinks. The acidic $\mathrm{pH}$ of phosphoric acid is a smaller amount than 3 that is the same as ethanoic acid. Makers add an oversized quantity of sugars in these drinks therefore so it does not taste like acid. In order to keep water sterile, a high concentration of phosphoric acid is added which makes the $\mathrm{pH}$ of drink acidic. Regular use of soft drinks (1-.5L/wk.) makes the teeth soft [19].

\section{Tooth Erosion}

Soft drink contains sugars as well as various natural acids and they are involved as an extraneous reason in the development of dental erosion [20].

Dental erosion isn't a disease and it's not caused by a microorganism. It happens when an acid dissolves the exhausting tissue of the tooth. Phosphoric acid is principally found in soft drinks, while citric acid in lemon and lime tasteful drinks. Any of this acid will erode tooth enamel. Dental erosion by acidic carbonated drinks seems to be growing drawbacks [21].

All soft drinks and drinks tested had acidic pH: 1.8-3.5 which is lower than the integral $\mathrm{pH}$ of tooth enamel and soft drinks with lower $\mathrm{pH}$ precipitated extra enamel dissolution [22].

Anecdotal proof exists that the regular propensity for rinsing carbonated beverages around the mouth before gulping can also enlarge the chance of erosion [23].

Calcium in saliva works to remineralize the teeth once exposure to the touch of wearing acid however with the inflated consumption of drinks it's not enough. Folks typically consume drinks over the course a daily which implies acid floods into the mouth anytime you are taking a sip of the drink, these attacks will twenty minutes and this method begins once more anytime a sip is taken [24].

\section{Effects on Bone}

Carbonated soft drinks are particular might be related to lower bone mineral density. Caffeine component is present in most of the soft drinks and this component indistinguished as a hazard factor for osteoporosis [25-27].

Phosphorus is an imperative supplement for bone health. The excessive dietary phosphorous has adverse effects on bone health [28]. Phosphorus is consumed in the form of phosphoric acid in soft drinks [29].

Soft drinks have phosphoric acid that allows inhibiting calcium absorption and contributing to an imbalance that causes a lack of calcium [25]. In wealthy western population, consumption of carbonated soft drink is very popular Especially in youth [30] Small scales studies specify that high consumption of carbonated soft drink especially soft drinks decrease bone mineral accumulation and rise fracture risk

\section{[30-33].}

A few observational works detailed that soft drinks is harmful to adolescent girls' bone health but not to boys. Such an affiliation might be mostly credited to the relocation of milk and other calcium rich substances or the immediate impact of soft drink elements (phosphoric acid, citric acid and caffeine) on bone [34].

\section{Effect on Kidneys when Rehydrated with a Soft Drink}

The imbalance intake of food and beverages, even plain water, can have adverse effects on the health of a person. The degree of renal injury is affected by the type of fluid taken as the hydrant after one hour of exposure to heat stress [35]. In their experiment, Garcia-Arroyo et al. (2016) gave the rats either plain water or $11 \%$ fructose-glucose solution, which has similar concentration to that of the soft drinks, for two hours after the exposure to heat stress.it was observed that the activation of vasopressin and Aldo-reductase pathways and enhanced renal oxidative stress, leads to the renal inflammation in the experimental group of rats. It was found that cyclic dehydration causes renal injury. However, the renal injury is found more in the group drinking $11 \%$ fructose-glucose solution than those drinking plain water, during the immediate rehydration period. Thus, an important message from this paper was that, after being dehydrated, the fluid of preference for rehydration should be plain water and not a sugar drink [35, 36].

\section{ROLE IN NON-ALCOHOLIC FATTY LIVER DISEASE}

Non-alcoholic fatty liver disease (NAFLD) is the continuous delivery of free fatty acids to the liver from the visceral fats or from the inflated activity of fatty food [37]. Today, NAFLD is a vital rising health issue. Many liver diseases, such as simple fatty liver (steatosis), nonalcoholic steatohepatitis (NASH) and cirrhosis, also come under the category of NAFLD [38]. It also results in obesity and many other health-related problems such as cardiovascular diseases, diabetes, and hypertension [39]. These diseases are collectively known as metabolic syndrome. It is observed that $70 \%$ of patients with liver disease have metabolic syndrome and 30\% of patients with metabolic syndrome have liver disease [40]. Today, two types of soft drinks are being used; regular soft drinks which are sweet with sugar (fructose) and diet soft drinks which are sweet with noncaloric sweet (aspartame) [41]. Fructose is sweet and cheap, therefore, it is used in commercial drinks and sweets [42]. Worldwide, soft drinks are the leading cause for added sugar in the diet. Recent studies suggest that intake of fructose through soft drinks increases the risk of obesity, induced insulin resistance and other diseases [42-44].

\section{ROLE IN PANCREATIC CANCER}

Sugar-sweetened soft drinks are a great source of absorbable sugars and can be related to an extended danger of obesity and diabetes. Diabetes mellitus and a food regimen high in sugar 
load are both important risk factors leading to biliary tract cancer $[6,45]$. Biliary tract cancers include tumors of the bile ducts inside and outdoor the liver, as properly as gallbladder cancer. Little is known about the motives of biliary tract cancer, however rising evidence indicates that excess body weight [46] and type 2 diabetes [47] may increase the risk of biliary tract cancer. Moreover, potential studies have discovered a sturdy high-quality association between fasting blood glucose concentration and the danger of biliary tract cancer and gallbladder cancer [48]. The basic mechanisms that might link increased blood glucose concentration to gallbladder cancers are still unclear, but growth-promoting consequences of insulin and insulin-like increase factors are possible mechanisms $[49,50]$.

\section{ROLE IN HYPERTENSION}

Hypertension or high blood pressure is a long-term medical condition in which the blood pressure in the arteries is continuously increased. Internationally, hypertension is a common health problem. Internationally, in the grownup population, 26 percent of people are reported to have high blood pressure. Obesity, low physical activity, high consumption of alcohol, high sodium intake, and low potassium intake are the well-known risk factors for hypertension [51, 52]. Some animal studies have reported on the role of sex hormones in developing hypertension as a result of sugar-sweetened beverages consumption [53], so it might be possible as with humans. Even though recent studies have reported associations between hypertension and high consumption of sugar-sweetened beverages [54, 55], it is still unclear whether the association between sugarsweetened beverages consumption and risk of hypertension is caused by the sugar-sweetened beverages per se, or through some other mechanism [56].

\section{ROLE IN CARDIOVASCULAR DISEASES}

The most common cause of death worldwide is cardiovascular disease. There is an interest to control its risk factors, in order to reduce its effects [57]. Increased consumption of sugar-sweetened beverages, often sweetened with sugar (fructose) has been associated with rising obesity rates which may lead to cardiovascular diseases [58, 59].

\section{CONCLUSION}

Our diet becomes part of our body. It is necessary to see what we are eating and drinking. It is necessary to shift lifestyle towards more healthy choices. The amount and frequency of consumption of carbonated soft drinks can be reduced in favor of healthy choices such as water, milk and natural juices.

\section{LIST OF ABBREVIATIONS}

GERD = Gastroesophageal Reflux Disease

NAFLD $=$ Non-Alcoholic Fatty Liver Disease

\section{CONFLICT OF INTEREST}

Declared none.

\section{ACKNOWLEDGEMENTS}

Declared none.

\section{REFERENCES}

[1] Alnusayri MO, Khattak AU, Gudipaneni RK, Patil SR. Knowledge, attitude and practices regarding carbonated beverages among the population of Aljouf province. Int $\mathbf{J}$ Med Res Prof 2017; 3(1): 1-4.

[2] Pai NR, Patil SS. A novel RP-HPLC method for quantitative determination of an angina pectoris drug and related substance. Res J Pharm Technol 2013; 6(9): 1014-18.

[3] Kharde A, Deshpande J, Phalke D. Knowledge, Attitude and Practices (KAP) regarding carbonated drinks among students of medical college of western Maharashtra. Int J Med Sci Public Health 2013; 2(4): 912.

DOI: $10.5455 /$ ijmsph.2013.250620133

[4] Haq N. A Survey on soft drinks intake behaviour among university going students. Bangladesh: East West University 2018.

[5] Hassanein GH, Farag AI, Ahmad MM. Effect of carbonated soft drinks consumption on the bone of Wistar albino rat: A histomorphometric study. J Am Sci 2016; 12(8): 78-84.

[6] Zappia V. Preface. Cancer Treat Res 2014; 159: i-xi.

[7] Giriwono PE, Andarwulan N, Rimbawan R, Muchtadi D. Consumption of carbonated beverages and the risk for gastrointestinal disease: A systematic review. J Nutr Food Res 2014; 37(1): 69-76.

[8] Szente M. Book review: Recent advances in epilepsy research. Cell Biochem Funct 2005; 23(4): 293. DOI: 10.1002/cbf.1213

[9] Gabrielesson B. Book review: Molecular biology of circadian rhythms. Cell Biochem Funct 2005; 23(4): 293.

DOI: $10.1002 / \mathrm{cbf} .1242$

[10] Butterworth PJ. Book review: Lehninger: principles of biochemistry. Cell Biochem Funct 2005; 23(4): 293-4. DOI: $10.1002 /$ cbf. 1216

[11] Viola Magni M P. Book review: Cytokines and joint injury. Cell Biochem Funct 2005; 23(4): 294. DOI: 10.1002/cbf.1229

[12] Cuomo R, Sarnelli G, Savarese MF, Buyckx M. Carbonated beverages and gastrointestinal system: Between myth and reality. Nutr Metab Cardiovasc Dis 2009; 19(10): 683-9. DOI: 10.1016/j.numecd.2009.03.020

[13] Sørensen LB, Møller P, Flint A, Martens M, Raben A. Effect of sensory perception of foods on appetite and food intake: A review of studies on humans. Int J Obes Relat Metab Disord 2003; 27(10): 1152-66. DOI: 10.1038/sj.ijo.0802391 
[14] Verhagen JV, Engelen L. The neurocognitive bases of human multimodal food perception: Sensory integration. Neurosci Biobehav Rev 2006; 30(5): 613-50.

DOI: 10.1016/j.neubiorev.2005.11.003

[15] Li W, Liu J, Chen S, Wang Y, Zhang Z. Prevalence of dental erosion among people with gastroesophageal reflux disease in China. J Prosthet Dent 2017; 117(1): 48-54.

DOI: 10.1016/j.prosdent.2016.04.029

[16] Fiorentino E. The consumption of snacks and soft drinks between meals may contribute to the development and to persistence of gastro-esophageal reflux disease. Med Hypotheses 2019; 125: 84-8. DOI: 10.1016/j.mehy.2019.02.034

[17] Johnson T, Gerson L, Hershcovici T, Stave C, Fass R. Systematic review: The effects of carbonated beverages on gastro-oesophageal reflux disease. Aliment Pharmacol Ther 2010; 31(6): 607-14. DOI: 10.1111/j.1365-2036.2010.04232.x

[18] Agrawal A, Tutuian R, Hila A, Freeman J, Castell DO. Ingestion of acidic foods mimics gastroesophageal reflux during pH monitoring. Dig Dis Sci 2005; 50(10): 1919-20. DOI: $10.1007 / \mathrm{s} 10620-005-2961-6$

[19] Damle SG, Bector A, Saini S. The effect of consumption of carbonated beverages on the oral health of children: A study in real life situation. Pesqui Bras Odontopediatria Clin Integr 2011; 11(1): 35-40. DOI: 10.4034/PBOCI.2011.111.05

[20] Hans R, Thomas S, Garla B, Dagli RJ, Hans MK. Effect of various sugary beverages on salivary $\mathrm{ph}$, flow rate, and oral clearance rate amongst adults. Scientifica (Cairo) 2016; 2016: 1-6. DOI: $10.1155 / 2016 / 5027283$

[21] Colombo M, Dagna A, Moroni G, Chiesa M, Poggio C, Pietro-cola G. Effect of different protective agents on enamel erosion: An in vitro investigation. J Clin Exp Dent 2019; 11(2): e113-e38. DOI: $10.4317 /$ jced.55278

[22] Nyan M. Win A, Tun YA, et al. Acidity and effect on enamel dissolution of ten commonly consumed soft drinks/beverages in Myanmar. Myanmar Dental J 2017; 24(1): 27-31.

[23] Levine R, Stillman-Lowe C. Dental erosion and erosive tooth wear. The Scientific Basis of Oral Health Education. Switzerland: Springer 2018; pp. 49-56.

DOI: 10.1007/978-3-319-98207-6_6

[24] Health Equalities Group. Soft drinks \& dental health. 2017 available at: http://www.foodactive.org.uk/wp-content/uploads/2016/07/GULP-5-Soft-Drinks-and-Dental-Health-v1.pd $\mathrm{f}$

[25] Tucker KL, Morita K, Qiao N, Hannan MT, Cupples LA, Kiel DP. Colas, but not other carbonated beverages, are associated with low bone mineral density in older women: The Framing-ham osteoporosis study. Am J Clin Nutr 2006; 84(4): 936-42. DOI: $10.1093 / \mathrm{ajcn} / 84.4 .936$
[26] Massey LK, Whiting SJ. Caffeine, urinary calcium, calcium metabolism and bone. J Nutr 1993; 123(9): 1611-14. DOI: 10.1093/jn/123.9.1611

[27] Rapuri PB, Gallagher JC, Kinyamu HK, Ryschon KL. Caffeine intake increases the rate of bone loss in elderly women and interacts with vitamin D receptor genotypes. Am J Clin Nutr 2001; 74(5): 694-700. DOI: 10.1093/ajcn/74.5.694

[28] Vorland CJ, Stremke ER, Moorthi RN, Hill Gallant KM. Effects of Excessive dietary phosphorus intake on bone health. Curr Osteoporos Rep 2017; 15(5): 473-82. DOI: $10.1007 / \mathrm{s} 11914-017-0398-4$

[29] Maslin K, Dennison E, Eds. Diet and Bone Health. USA: Elsevier Inc. 2014.

[30] Wagner M, Kunsch S, Duerschmied D, et al. Transgenic overexpression of the oncofetal RNA binding protein KOC leads to remodeling of the exocrine pancreas. Gastroenterology $2003 ; 124(7): 1901-14$.

DOI: $10.1016 / \mathrm{S} 0016-5085(03) 00402-5$

[31] Wyshak G. Teenaged girls, carbonated beverage consumption, and bone fractures. Arch Pediatr Adolesc Med 2000; 154(6): 610-13. DOI: 10.1001/archpedi.154.6.610

[32] Vatanparast H, Whiting SJ. Adolescence, the optimum time to maximize bone mass through calcium \& vitamin D. Whitehall-Robins Rep 2005; 14(2): 46-7.

[33] Al-Raddadi R, Bahijri S, Borai A, AlRaddadi Z. Prevalence of lifestyle practices that might affect bone health in relation to vitamin D status among female Saudi adolescents. Nutrition 2018; 45: 108-113. DOI: 10.1016/j.nut.2017.07.015

[34] Liu ZM, Tse SLA, Chen B, et al. Dietary sugar intake does not pose any risk of bone loss and non-traumatic fracture and is associated with a decrease in all-cause mortality among Chinese elderly: Finding from an 11-year longitudinal study of Mr. and Ms. OS Hong Kong. Bone 2018; 116: 154-61.

DOI: 10.1016/j.bone.2018.07.011

[35] García-Arroyo FE, Cristóbal M, Arellano-Buendía AS, et al. Rehydration with soft drink-like beverages exacerbates dehydration and worsens dehydration-associated renal injury. Am J Physiol Regul Integr Comp Physiol 2016; 311(1): R5765. DOI: 10.1152/ajpregu.00354.2015

[36] García-Arroyo FE, Tapia E, Blas-Marron MG, et al. Vasopres-sin mediates the renal damage induced by limited fructose rehydration in recurrently dehydrated rats. Int J Biol Sci 2017; 13(8): 961-75. DOI: 10.7150/ijbs.20074

[37] Grattagliano I , D'Ambrosio G, Palmieri VO, et al. Improving nonalcoholic fatty liver disease management by general practi-tioners: A critical evaluation and impact of an educational training program. J Gastrointest Liver Dis 2008; 17(4): 389-94. 
[38] Ferder L, Ferder MD, Inserra F. The role of high-fructose corn syrup in metabolic syndrome and hypertension. Curr Hyper-tens Rep 2010; 12(2): 105-112. DOI: $10.1007 / \mathrm{s} 11906-010-0097-3$

[39] Ma J, Fox CS, Jacques PF, et al. Sugar-sweetened beverage, diet soda, and fatty liver disease in the Framingham Heart Study cohorts. J Hepatol 2015; 63(2): 462-9. DOI: $10.1016 /$ j.jhep.2015.03.032

[40] Alberti KG, Eckel RH, Grundy SM, et al. Harmonizing the metabolic syndrome: A joint interim statement of the international diabetes federation task force on epidemiology and prevention; National heart, lung, and blood institute; American heart association; World heart federation; International Atherosclerosis Society; and International Association for the Study of Obesity. Circulation 2009; 120(16): 1640-5. DOI: 10.1161/CIRCULATIONAHA.109.192644

[41] Siddiqi Z, Karoli R, Fatima J, Khanduri S, Varshneya S, Ahmad SS. Soft drinks consumption and the risk of nonalcoholic fatty liver disease. J Assoc Physicians India 2017; 65: 28-32.

[42] Carvalho CT, de Souza MZ, Arbex N, et al. The role of fructose in public health and obesity. Health 2018; 10(4): 434-41. DOI: $10.4236 /$ health.2018.104035

[43] Gaby AR. Adverse effects of dietary fructose. Altern Med Rev 2005; 10(4): 294-306.

[44] Zelber-Sagi S, Godos J, Salomone F. Lifestyle changes for the treatment of nonalcoholic fatty liver disease: A review of observational studies and intervention trials. Therap Adv Gastroenterol 2016; 9(3): 392-407.

DOI: $10.1177 / 1756283 \times 16638830$

[45] Barone E, Corrado A, Gemignani F, Landi S. Environmental risk factors for pancreatic cancer: An update. Arch Toxicol 2016; 90(11): 2617-42. DOI: 10.1007/s00204-016-1821-9

[46] Larsson SC, Wolk A. Obesity and colon and rectal cancer risk: A meta-analysis of prospective studies. Am J Clin Nutr 2007; 86(3): 556-65. DOI: 10.1093/ajen/86.3.556

[47] Ogonowski M, Hansson S, Duberg J. Status and vertical sizedistributions of a pelagic mysid community in the northern Baltic proper. Boreal Environ Res 2013; 18(1): 1-18.

[48] Rapp K, Schroeder J, Klenk J, et al. Fasting blood glucose and cancer risk in a cohort of more than 140,000 adults in Austria. Diabetologia 2006; 49(5): 945-52. DOI: $10.1007 / \mathrm{s} 00125-006-0207-6$
[49] Suzuki H, Roa JC, Kawamoto T, et al. Expression of insulinlike growth factor I receptor as a biomarker for predict-ing prognosis in biliary tract cancer patients. Mol Clin Oncol 2015; 3(3): 464-70. DOI: 10.3892/mco.2015.515

[50] Makarem N, Bandera EV, Nicholson JM, Parekh N. Consumption of sugars, sugary foods, and sugary beverages in relation to cancer risk: A systematic review of longitudinal studies. Annu Rev Nutr 2018; 38(1): 17-39.

DOI: 10.1146/annurev-nutr-082117-051805

[51] Polonikov AV, Vialykh EK, Churnosov MI, et al. The C718T polymorphism in the 3 '-untranslated region of glutathione peroxidase- 4 gene is a predictor of cerebral stroke in patients with essential hypertension. Hypertens Res 2012; 35(5): $507-$ 12. DOI: $10.1038 / \mathrm{hr} .2011 .213$

[52] Malik VS. Sugar sweetened beverages and cardiometabolic health. Curr Opin Cardiol 2017; 32(5): 572-9. DOI: $10.1097 / \mathrm{HCO} .0000000000000439$

[53] Galipeau D, Verma S, McNeill JH. Female rats are protected against fructose-induced changes in metabolism and blood pressure. Am J Physiol Heart Circ Physiol 2002; 283(6): H2478-84. DOI: 10.1152/ajpheart.00243.2002

[54] Malik AH, Akram Y, Shetty S, Malik SS, Yanchou Njike V. Impact of sugar-sweetened beverages on blood pressure. Am J Cardiol 2014; 113(9): 1574-80.

DOI: $10.1016 /$ j.amjcard.2014.01.437

[55] Song HJ, Paek YJ, Choi MK, et al. Gender Differences in the relationship between carbonated sugar-sweetened beverage intake and the likelihood of hypertension according to obesity. Int J Public Health 2017; 62(5): 573-81.

DOI: $10.1007 / \mathrm{s} 00038-016-0855-3$

[56] Kang Y, Kim J. Soft drink consumption is associated with increased incidence of the metabolic syndrome only in women. Br J Nutr 2017; 117(2): 315-24.

DOI: $10.1017 / \mathrm{S} 0007114517000046$

[57] Licht N, Rozanski EA, Rush JE. Vasopressor use in 41 critically ill cats (2007-2016). Can Vet J 2018; 59(11): 117580.

[58] Narain A, Kwok CS, Mamas MA. Soft drink intake and the risk of metabolic syndrome: A systematic review and metaanalysis. Int J Clin Pract 2017; 71(2): 1-12. DOI: $10.1111 /$ ijcp.12927

[59] Yu E, Malik VS, Hu FB. Reprint of: Cardiovascular Disease Prevention by Diet Modification. J Am Coll Cardiol 2018; 72(23): 2951-63. DOI: 10.1016/j.jacc.2018.10.019 